\title{
Community Preparedness in Prevention and Control of Covid-19 in Jakarta and Its Surroundings
}

\author{
${ }^{1}$ Wahyu Sulistiadi* ${ }^{2,3}$ Sri Rahayu, ${ }^{1} \mathrm{Al}$ Asyari, ${ }^{2,4}$ Meita Feruswati, ${ }^{5}$ Hafiizhoh Fithriyyah, \\ ${ }^{1}$ Hikmahwati, ${ }^{2}$ Gebby Oktapuri \\ ${ }^{I}$ Faculty of Public Health, Universitas Indonesia \\ ${ }^{2}$ The Institute of Research and Community Services, Universitas Indonesia, \\ ${ }^{3}$ Postgraduate in Public Health Science, Faculty of Public Health, Universitas Muhammadiyah Prof Dr \\ Hamka, \\ ${ }^{4}$ Public Health Program, Universitas Muhammadiyah Prof DR Hamka, Magister Program, Nursing Faculty of \\ Universitas Indonesia \\ * Corresponding author: wahyufphui@gmail.com
}

\begin{abstract}
Jakarta is being a barometer for Indonesia in Covid-19 controlling, if the government and its people are success, other regions will emulate them in saving Indonesia. Community preparedness is a direct effect of the government's efforts to lead the war against Covid-19. The study design used was a cross sectional study design involving 465 samples of the Jakarta's people and its surroundings during 2 months. The results of the study indicate that community preparedness in the form of attitudes, desires, obedience and community participation is significant to the implementation of the effectiveness of PSBB in controlling Covid-19. The determinant factor is attitude of the community that understands and accepts PSBB. Unfortunately there are some people still impatient with outside activities and are not disciplined in the health protocol. The government needs to firmly enforce the opening and closing of the PSBB if a decrease in the number of transmission has not occurred.
\end{abstract}

Keywords: social restrictions, community preparedness, control, Covid-19

\section{INTRODUCTION}

Indonesia as a country affected by the pandemic Covid-19 strive continuously to control its spread and transmission by several times changing the organization management with the aim of being able to successfully reduce the rate of acceleration of transmission which has fatal consequences. This country has implemented LargeScale Social Restrictions (PSBB) which is a lockdown model in Indonesia as outlined in the mandate of Government Regulation Number 21 of 2020 to prevent the transmission and control of Covid-19. Even though the infected population is still high, there were many areas do not continue it and until September 2020 only a few areas are still implementing PSBB. The classical reason of the government for relaxing or stop PSBB is the economic problem, which resulted in an extended public health emergency with increased morbidity and mortality of Covid-19 patients. People are starting to loosen up, do not optimally implementing health protocols anymore and seem to do the routine activity again without concerning the health protocols. This study explores information from the people of Jakarta and its surroundings regarding the preparedness of implementation PSBB. The transmission trend has not been stable yet and even has increased, so the PSBB is still attractive and worthy of repeated implementation even more stringently.
DKI Jakarta as the province with the highest testing, tracing and treatment until 9 September 2020 still shows an increase in positive rates in the last 4 weeks, even though the transitional PSBB is still implemented. National data updated per 9 September 2020 showed 203,342 positive cases, 49,806 treated cases, 145,200 recovered and 8,336 deaths. Meanwhile, DKI Jakarta data shows 19,837 positive cases, 4,554 treated, 37,243 recovered, 1,347 deaths, and 6,691 isolated independently. This data is worrying for a country that has experienced a public health emergency for almost 7 months. ${ }^{[1]}$

\section{METHOD}

The study design used was a cross sectional study design with a quantitative approach using a questionnaire distributed through social media with google form to the people of DKI Jakarta and its surroundings, which are the epicenter of the spread of Covid-19 in Indonesia. This study uses primary data taken directly from the community and provides responses through questionnaires. The population is the people of Jakarta and its surroundings, while the total sample was obtained 465 respondents who were conducted from August to September 2020. The analysis was performed using multiple regression analysis to see the preparedness determinant factor for the effectiveness of the 
complement the conditions that occurred, a qualitative approach was carried out with a case study design in Jakarta through interviews with competent informants on a private Indonesian television program on September 9 2020 at 08.00 PM. Informants ranging from the Covid-19 National Task Force, the Governor of DKI Jakarta and health officials in Jakarta.

\section{RESULTS}

The restriction models in controlling Covid-19 in different countries differ in applying their restriction rules, it's starting from social restrictions to lockdown. The more stringent and obeyed by the community, the more effective the success will be. Jakarta and its surrounding areas have conducted PSBB many times, but have not shown encouraging results.

From this study, which explores the knowledge of the people of Jakarta and its surroundings, almost all of them understand the dangers of Covid-19 and its transmission, only about $7 \%$ do not understand. In taking a public attitude by preventing it through PSBB, only $4 \%$ disapproved. However, once people are asked to do activities at home, the number of people whom do not agree increases quite high, up to 53\%. From this research it will be answered why Jakarta and other regions in Indonesia are still increasing for infected cases and death rates, even though in other countries the rate of transmission has decreased as is done in other countries. The following results were obtained from the people of Jakarta and its surroundings with due regard to:

\section{Attitude of the community}

This attitude is manifested in the readiness of the community to respond consistently to the Covid-19 pandemic situation with $96 \%$ agree that the spread and transmission can be prevented and controlled through social restrictions. This will be different when the community is asked for their attitude to return carrying out activities outside the home without caring about the implementation of PSBB, around $46 \%$ agree with it. These two ambiguous attitudes of the community led the government to be at odds with continuing the PSBB or modifying the form of the PSBB. Of course all of this will result in the long wait of the Covid-19 transmission curve slope. The lockdown or PSBB which implemented by various countries to prevent changes in the trend of community mobility from various categories of places including public places, entertainment, workplaces, markets and schools has been temporarily suspended.

\section{The desire of the community}

The desire of the community, from this study, can be seen from closing public spaces that it still needs to be done and it must be ensured that it is not relaxed until Covid-19 is controlled and there is a hope with the vaccine, Covid-19 can be controlled. The desire of the community is all the more needs for the conditions and situations to be fulfilled during the Covid-19 pandemic, such as limiting the mobility of the community to continue strive to control transmission by $90 \%$. The desire to open public facilities so that socio-economic life is turbulent again even though Covid-19 has not been controlled, only $40 \%$. There are $52 \%$ of the public's desire for a vaccine to control Covid-19, it turns out that people understand that it is not easy to get a vaccine in a short time.

Community preparedness in controlling Covid-19 can be displayed in attitudes, activities, desire for compliance and community participation. The attitude of the community can be seen from the compliance with preventive efforts with social restrictions. The community can adopt a different compliance attitude by returning to carrying out activities outside the home without caring about the implementation of the PSBB, this is driven by economic factors. This attitude also occurred in the Netherlands, which to some extent succeeded as expected in its implementation. Repression does not play a significant role in obedience, while intrinsic motivation (moral and social) results in better compliance. ${ }^{[2]}$

\section{Community compliance}

In terms of compliance, $83 \%$ of the people are still able to control Covid-19 by wearing masks, maintaining distance and washing their hands. Public compliance can be realized because people are still able to try to control Covid-19 by wearing masks, maintaining distance and washing hands. Community participation is in the form of individuals who are ready to call out if there are members of the community who do not wear masks outside the home and the community is ready to create a Covid-19 control task force to the RT, RW and even family level. The Covid-19 contagious disease is a global public health problem that is threatening the entire world rapidly.

\section{Society participation}

Individual participation is quite high, 94\%, that is, they are ready to call out if there are community members who do not wear masks outside the home. This is in line with community participation with $95 \%$ ready to create a Covid-19 control task force to the RT RW level and even the family.

In order to achieve the effectiveness of the implementation of PSBB, from the aspect of community preparedness, which needs to be considered from the results of this study simultaneously, it needs to be accommodated and directed, namely Community Attitudes, Community Desires, community compliance and community participation. This can be obtained from the Multiple Regression Analysis that PSBB Effectiveness $=1.057+0.368 \times$ Community Attitude + $0.103 \times$ Public Desire +0.282 x community compliance $+0.113 \times$ Community Participation $+\varepsilon$. 
Table 1. The Effect of Community Involvement on the Effectiveness of PSBB

\begin{tabular}{|c|c|c|c|c|c|c|c|c|c|c|}
\hline \multirow[b]{2}{*}{ Model } & & \multicolumn{2}{|c|}{ Unstandardized Coefficients } & \multirow{2}{*}{$\begin{array}{c}\text { Standardized Coefficients } \\
\text { Beta }\end{array}$} & \multirow[b]{2}{*}{$t$} & \multirow[b]{2}{*}{ Sig. } & \multicolumn{2}{|c|}{$95.0 \%$} & \multicolumn{2}{|c|}{ Collinearity } \\
\hline & & B & Std. Error & & & & $\begin{array}{l}\text { Lower } \\
\text { Bound }\end{array}$ & $\begin{array}{l}\text { Upper } \\
\text { Bound }\end{array}$ & Tolerance & VIF \\
\hline \multirow{6}{*}{1} & (Constant) & 1.057 & 0.450 & & 2.349 & 0.019 & 0.173 & 1.941 & & \\
\hline & Community Attitude & 0.368 & 0.041 & 0.365 & 8.896 & 0.000 & 0.287 & 0.449 & 0.964 & 1.038 \\
\hline & Community activities & 0.099 & 0.079 & 0.056 & 1.257 & 0.209 & -0.056 & 0.255 & 0.826 & 1.211 \\
\hline & Public desire & 0.103 & 0.033 & 0.131 & 3.076 & 0.002 & 0.037 & 0.168 & 0.895 & 1.118 \\
\hline & Community compliance & 0.282 & 0.065 & 0.184 & 4.342 & 0.000 & 0.154 & 0.410 & 0.905 & 1.105 \\
\hline & Community participation & 0.113 & 0.051 & 0.099 & 2.187 & 0.029 & 0.011 & 0.214 & 0.789 & 1.268 \\
\hline
\end{tabular}

a. Dependent Variable: PSBB Effectiveness

From all of forms of community involvement, the variable with the determinant factor that influence on the effectiveness of PSBB implementation is the variable of public attitudes because the value of the Beta constant ( standardized coefficient $)=0.365$ is the highest constant value compared to other variables.

\section{DISCUSSIONS}

Regression analysis showed a significant positive correlation between the number of confirmed cases before lockdown and mortality up to sixty days. Furthermore, the analysis of deaths against the incidence rate of new cases displayed a stronger significant positive relationship, confirming that the burden of cases before community containment have influenced mortality across the Italian territory. Beta coefficients indicated about 2 deaths up to sixty days for every additional patient with confirmed Covid-19 before lockdown, and 37 deaths for every new infected subject per day until the decree of March 9, 2020. ${ }^{[2]}$

Study in Italia, offers initial evidence that the Covid19 pandemic can be suppressed by a lockdown. In addition, other parameters such as demographic of population, density of populations, the parameters of weather, economy, and infrastructure of healthcare systems may be considered in the studies considering that it may be effective on Covid-19 pandemic. As a result, the application of lockdown by governments is also thought to be effective on psychology, environment and economy with it being effective on Covid-19. ${ }^{[3]}$

During the study period I Italia, mobility restriction was inversely related to the daily number of newly diagnosed SARS-CoV-2 positive cases only after the second, more effective lockdown, with a peak in the curve of diagnosed cases of infection occurring 14 to 18 days from lockdown in the three regions and 9 to 25 days in the included provinces. An effective reduction in transmission must have occurred nearly immediately after the tighter lockdown, given the lag time of around 10 days from asymptomatic infection to diagnosis. The period from lockdown to peak was shorter in the areas with the highest prevalence of the infection. This effect was seen within slightly more than one week in the most severely affected areas. ${ }^{[4]}$

It appears that the less rigid lockdown led to an insufficient decrease in mobility to reverse an outbreak such as COVID-19. With a tighter lockdown, mobility decreased enough to bring down transmission promptly below the level needed to sustain the epidemic. ${ }^{[4]}$

This also happened in Jakarta, which reimplemented Large-Scale Social Restrictions (PSBB) as an emergency brake measure related to the Covid-19 pandemic. Jakarta is making restriction efforts again by means of pulling the emergency brake which has to be carried out in the form of large-scale restrictions such as the early days of the pandemic. Of course it is no longer a transitional PSBB, but the PSBB as where it was in the beginning. This is the emergency brake that we pulled, as stated by the Governor of DKI Jakarta. Although the PSBB policy which was then continued with the transition PSBB was one of the efforts by the DKI Provincial Government to reduce the spread of the corona virus, however in recent days, the number of positive cases of Covid-19 has recorded the highest increase in records. ${ }^{[5]}$

The weekly positivity rate in Jakarta in August September is always above 10 percent, exceeding the WHO safe limit of 5 percent. The Jakarta city also has concerns about the availability of hospitals to handle Covid-19 patients which also affects the increasingly limited burial sites for corona patients.

The PSBB that will be carried out, as has been implemented by Jakarta, refers to the Minister of Health Regulation No.9 of 2020, including: school and work vacations; restrictions on religious activities; restrictions on activities in public places or facilities; restrictions on social and cultural activities; restrictions on transportation modes; and restrictions on other activities specifically related to defense and security aspects. ${ }^{[6]}$ From the statement of the number one person in Jakarta, it is indeed feasible to do so and the readiness of the community has also been supportive, as in this study, the attitude of the community in general supports the imposition of social restrictions again if the conditions of transmission continue to increase.

The Head of the DKI Jakarta Public Health Office is also remind that there was a more comprehensive analysis of how residents from other provinces could potentially transmit this infectious virus in areas, including Jakarta. There may be transmission between people from outside the area to Jakarta or vice versa. DKI Jakarta agrees with a more massive intervention, as previously stated, the PSBB will be more stringent. If 
(PSBB or intervention) is only in Jakarta, of course it is less effective. ${ }^{[7]}$

The Governor of DKI Jakarta explained that the situation of the transmission of Covid-19 in Jakarta in September 2020 entered into an emergency condition based on three data conditions on patient mortality, use of isolation beds, the use of ICU for Covid-19 patients which shows that they can exceed the threshold if the PSBB is not carried out again. The trend of increasing Covid-19 cases in Jakarta has caused the availability of 4,800 isolation beds to be full if conditions do not change. ${ }^{[8]}$

If we look at ASEAN countries that have been successful in overcoming Covid-19, it turns out that the community's participation is really important as follows: ${ }^{[9]}$

a) There are health-volunteers across the country working at the village level near and far. They are mostly women who know their community very well. Each, depending on location and community, must care for up to 10 families. They visit various households, tell them about the pandemic. Besides that, they also got their health checked. Anyone who enters or leaves the community does not go unnoticed, especially during a pandemic. In addition, these volunteers work closely with health workers at all district and provincial levels. Thereby strengthening a strong health system at all levels helping to reduce the pandemic.

b) Applying general precautions, as Thailand did. Thailand is the only country in ASEAN that has implemented "universal precautions" in fighting Covid-19. Public health officials urge everyone to wear face masks at all times and maintain personal hygiene as soon as the first cases were announced. Such an approach allows most people to prevent the spread of the virus. So, random testing is not required. In contrast, testing has been performed only for these confirmed cases. According to the World Health Organization, Thailand carries out 150 tests for every confirmed positive case, which is considered a high ratio. WHO acknowledges that wearing masks can help prevent the spread of the virus.

c) Forming a resilient society, without the participation and cooperation of the community that follows the Health protocols of health professionals and the government. The efforts to save yourself is a tremendous task.

d) Quality of leadership: Government officials have given full appreciation and concern to the community by continuing to campaign for health protocols and healthy lifestyles.

e) Right time for action: judging from the timeline of the social restriction, isolation and quarantine system at the right time and simultaneously for all areas at risk.

f) Fact-based communication, community communication is always carried out based on facts and data which makes it easier for public awareness to keep the environment healthy and clean from Covid-19.

In general, people in Indonesia did not clearly understand the COVID-19 epidemic, including transmission, management, and how to avoid it. This misunderstanding can extend the pandemic and the length of large-scale social restrictions. The central or regional government, together with local leaders/religious leaders and the local security apparatus, have the responsibility of delivering education, precise information, and accurate and appropriate communication strategies that align with the culture of the community, to increase community empathy and sympathy. The government and community must develop strategic, concrete, and decisive policies that are not confusing to the public and learn from the success of other countries' experiences with the control of COVID-19 transmission. ${ }^{[10]}$

\section{CONCLUSIONS}

The implementation of the PSBB in Jakarta and its surrounding areas is generally understood by the community as a manifestation of the community's attitude, but its implementation has not been effective yet because it is not carried out simultaneously with the surrounding area, causing mobility to continue which opens up alternating transmissions. There are some people who are not obedient so that it will interfere with the success of the implementation of the PSBB which results in lengthening time and increasing number of victims. The implementation of PSBB alone will not control the transmission of the virus if the participation and readiness of the community is not followed in carrying out the Health protocol and the application of strict rules to shape the behavior of people who still do not care. Community participation preparedness can adopt and adapt the success stories of countries that have succeeded with their people in limiting the transmission of Covid-19.

\section{ACKNOWLEDGMENT}

Thanks to The Institute of Research and Community Services, University of Indonesia for sponsoring this research.

\section{REFERENCES}

[1]. Kementerian Kesehatan Republik Indonesia. Data Pemantauan Covid-19 DKI Jakarta [Internet]. Kementerian Kesehatan Republik Indonesia. 2020 [cited 2020 Oct 10]. Available from: https://corona.jakarta.go.id/id/datapemantauan 
[2]. Kuiper ME, Bruijn AL de, Folmer CR, Olthuis E, Brownlee M, Kooistra EB, et al. The intelligent lockdown: Compliance with COVID-19 mitigation measures in the Netherlands [Internet]. Netherlands; 2020. Available from: https://papers.ssrn.com/sol3/papers.cfm?abstr act_id=3598215

[3]. Atalan A. Is the lockdown important to prevent the COVID-19 pandemic? Effects on psychology, environment and economyperspective. Ann Med Surg [Internet]. 2020;56(June):38-42. Available from: https://doi.org/10.1016/j.amsu.2020.06.010

[4]. Vinceti M, Filippini T, Rothman KJ, Ferrari F, Goffi A, Maffeis G. Lockdown timing and efficacy in controlling COVID-19 using mobile phone tracking. EClinicalMedicine [Internet]. 2020;25:100457. Available from: https://www.thelancet.com/journals/eclinm/ar ticle/PIIS2589-5370(20)30201-

7/fulltext $\% 0 \mathrm{~A} \% 0 \mathrm{~A}$

[5]. Baswedan A. Anies Tarik Rem Darurat Berdasarkan 3 Data Ini [Internet]. detikNews.com. 2020 [cited 2020 Sep 20]. Available from: https://news.detik.com/berita/d-

5166604/anies-tarik-rem-daruratberdasarkan-3-data-ini

[6]. Baswedan A. Anies Tarik Rem Darurat, Jakarta PSBB Total [Internet]. CNN Indonesia, 2020. 2020. Available from: https://www.cnnindonesia.com/nasional/2020 0909133929-20-544417/anies-tarik-remdarurat-jakarta-psbb-total

[7]. Wijaya LD, Arjanto D. Dinas Kesehatan DKI: 30 Persen Pasien Positif Covid-19 Berdomisili Luar Jakarta [Internet]. TEMPO.CO. 2020 [cited 2020 Sep 18]. Available from: https://metro.tempo.co/read/1384482/dinaskesehatan-dki-30-persen-pasien-positifcovid-19-berdomisili-luar-jakarta\%0A\%0A

[8]. Baswedan A. Anies Tarik Rem Darurat, Jakarta Kembali ke PSBB Ketat [Internet]. kumparanNews.com. 2020 [cited 2020 Sep 19]. Available from: https://kumparan.com/kumparannews/aniestarik-rem-darurat-jakarta-kembali-ke-psbbketat-1uAPs3R8Py0

[9]. Chongkittavorn K. 7 secrets of Thai Covid-19 success [Internet]. bangkokpost.com. 2020 [cited 2020 Oct 14]. Available from: https:/www.bangkokpost.com/opinion/opini on/1939416/7-secrets-of-thai-covid-19success

[10]. Sulistiadi W, Rahayu S, Harmani N. Handling of Public Stigma on COVID-19 in Indonesian Society. Natl Public Heal J [Internet]. 2020; Special Is(1):70-6. Available from: http://journal.fkm.ui.ac.id/kesmas 